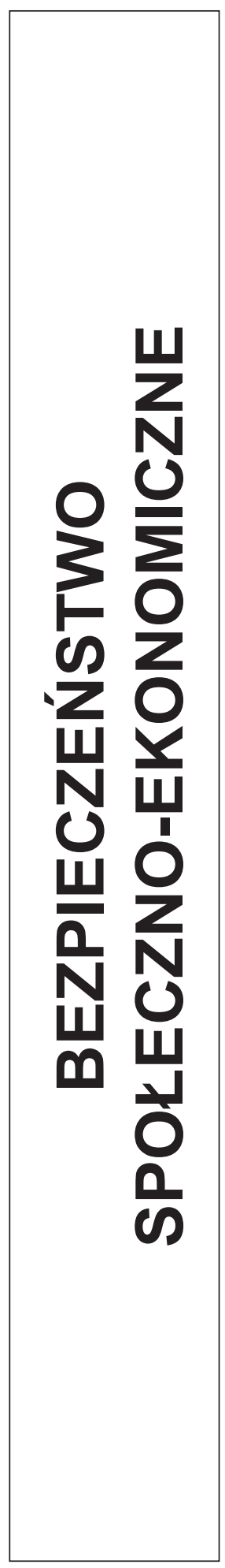





\section{Maciej WALKOWSKI}

Uniwersytet im. Adama Mickiewicza w Poznaniu

\section{PRZYCZYNY POWSTANIA GLOBALNEGO KRYZYSU FINANSOWEGO 2008+. ANALIZA I PORÓWNANIE WYBRANYCH OPINII}

Globalny kryzys finansowy 2008+ doprowadził do największego od ośmiu dekad wstrząsu w rozwoju gospodarki światowej, naznaczonego stagnacją i recesją, wyraźnie rosnącym bezrobociem i ogromnym niezadowoleniem społecznym. Jednocześnie w mediach elektronicznych, mających współcześnie olbrzymi wpływ na kształtowanie świadomości społecznej próby wyjaśnienia przyczyn bieżącego kryzysu, często miały i nadal niestety mają charakter uproszczony, powierzchowny, sensacyjny i chaotyczny, mieszcząc się w dominującej formule komunikowania się zwanej infotaitment. Tymczasem na polskim rynku wydawniczym na przestrzeni ostatnich kilku lat ukazało się co najmniej kilkanaście wartościowych publikacji naukowych, których analiza pozwala na rzetelne i obiektywne zdiagnozowanie problemu, z elementami towarzyszących temu kontrowersji i polemik włącznie. W prezentowanym artykule autor stara się uchwycić główne źródło sporu wokół przyczyn pojawienia się bieżącego kryzysu, dodatkowo kreśląc jego główne skutki i sposoby wyjścia z zapaści gospodarczej, jakie spowodował. Celem badawczym prezentowanego artykułu jest uchwycenie głównego źródła sporu wokół przyczyn pojawienia się bieżącego kryzysu, ze szczególnym zwróceniem uwagi na jego epicentrum, czyli Stany Zjednoczone. Dodatkowo w tekście ogólnie kreśli się skutki i sposoby wyjścia z zapaści gospodarczej, jakie kryzys 2008+ spowodował w gospodarce światowej. Aby precyzyjnie i bez subiektywnej interpretacji zaprezentować różne poglądy w omawianej kwestii, tekst celowo wzbogacony został w liczne, rozbudowane, interesujące i jak się wydaje niezbędne cytowania.

$$
* * *
$$

W regularnie publikowanych opracowaniach naukowych i opiniotwórczych tekstach prasowych formułowane są różne tezy wyjaśniające przyczyny pojawienia się obecnego światowego kryzysu finansowego i ekonomicznego. Krytycy współczesnej neoliberalnej wersji kapitalizmu w skali globalnej, zazwyczaj podkreślają spektakularny wzrost roli i znaczenia kapitału spekulacyjnego oraz błędy związane z polityką deregulacji rynków finansowych. Pojawiają się wśród nich opinie o niepohamowanej żądzy zysku, chciwości i ogólnym braku etyki zawodowej wśród bankierów i przedstawicieli instytucji z nimi współpracujących, typu agencje ratingowe (z wielką trójką Moody's, Fitch i $S \& P$ na czele). W środowisku tym podkreśla się też nadmierny wpływ przedstawicieli Wall Street na politykę finansową rządu amerykańskiego, co J. Bhagwatti określił jako The Wall Street-Treasury Complex. Z kolei zwolennicy neoliberalnej 
globalizacji ekonomicznej i finansowej głoszą pogląd, że główną odpowiedzialność za obecne zjawiska kryzysowe ponoszą nie rynki finansowe, lecz nieracjonalne działania władz w USA. Szczególnie krytykują oni błędną polityką monetarną prowadzoną przez System Rezerwy Federalnej Stanów Zjednoczonych, czyli Fed. Jak pisze Witold Orłowski, w powszechnej dyskusji chętnie zawęża się lista czynników, które odpowiadają za obecny kryzys, co spuentować można stwierdzeniem ,zbłądzili chciwi bankierzy, zbłądził niepodejmujący odpowiednich działań $F e d "$ ". Osoby przez całe życie wierzący w samoregulacyjną sprawność rynku, popularyzujące poglądy F. A. Von Hayeka skłonne są więc oskarżać o kryzys nadmiar polityki interwencji i regulacji oraz ogólnie błędną politykę gospodarczą państw. Z kolei osoby nieufne wobec działań deregulacyjnych, generalnie popierające poglądy innego wybitnego ekonomisty, czyli J. M. Keynesa za obecny stan gospodarki światowej skłonne są winić neoliberalne doktrynerstwo i politykę pozbawioną odpowiednich regulacji, czyli nadzoru i kontroli organów państwowych nad rynkiem finansowym. Tymczasem, jak się wydaje, lista czynników i zjawisk, które doprowadziły do obecnego kryzysu jest znacznie dłuższa, a jego interpretacja wyjątkowo niejednoznaczna i złożona (Szymański, 2009: 13-41).

Władysław Szymański, w swym bardzo interesującym opracowaniu naukowym Kryzys globalny. Pierwsze przybliżenie, podkreśla, że początek globalnego kryzysu finansowego, który następnie dotknął realnej sfery ekonomii i przerodził się w ogólnoświatowy kryzys gospodarczy rozpoczął się w sierpniu 2007 r. w Stanach Zjednoczonych. W owym czasie ogłoszono upadłość dwóch znaczących funduszy hedgingowych, należących do banku Bear Stearns. W owym czasie nastapiło załamanie na amerykańskim rynku substandardowych kredytów hipotecznych typu subprime. Za bezpośrednią przyczynę światowego kryzysu gospodarczego, uważa się pęknięcie bańki spekulacyjnej na amerykańskim rynku nieruchomości, którą zidentyfikowano w sierpniu 2002 roku, a za jej szczyt uważa się rok 2005, kiedy to wartość sprzedanych domów stanowiła pięciokrotność wartości sprzedaży domów z roku 1990. W owym czasie liczba sprzedanych domów podwoiła się, wzrastając z około 5 mln rocznie w 1990 r. do ponad $11 \mathrm{mln}$ w 2005 roku. Głównym czynnikiem tak dużego wzrostu wartości transakcji był wzrost cen nieruchomości w latach 1990-2005 o ponad 170\%. W 2008 r. oceniono, że amerykańskie instytucje finansowe udzieliły kredytów typu subprime podmiotom, które nie miały prawie żadnej zdolności kredytowej na sumę 700 mld dolarów. Jedyną podstawą zdolności kredytowej było błędne założenie, że ceny nieruchomości będą rosły o minimum kilkanaście procent rocznie. Nieruchomości uważano za bezpiecznq inwestycję, na której „nigdy się nie traciło", bo „ceny domów i mieszkań nigdy nie spadają” (ibidem).

W związku z tym Nouriel Roubini, który jako jeden z nielicznych znanych w świecie ekonomistów przestrzegał przed groźbą pojawienia się kryzysu, w książce Ekonomia kryzysu zauważył: „Były dziesiątki sygnałów, które ostatecznie doprowadziły do punktu zwrotnego. To, że nadejdzie kryzys było dla mnie oczywiste. Ludzie wierzyli w bzdurę, że ceny domów będą rosły o $20 \%$. Jeżeli to nie jest bańka, to co nią jest? Nie trzeba być geniuszem, by to dostrzec. [...] Ludzie wierzyli w rzeczy, w które nie powinni wierzyć, ufali ludziom, którym nie powinni ufać. Na rynku nie było dyscypliny, w zarządzaniu firmami popełniono błędy, w ramach instytucji finansowych istniały potężne konflikty interesów, Stanowa Komisja papierów wartościowych nie wykonywała swych obowiązów" (Roubini, Mihm 2011: 21-44). 
Pęknięcie bańki (lub bąbla, jak to określają niektórzy autorzy) na rynku nieruchomości oznaczało spadek cen domów. Wpływało to nie tylko na niewypłacalność osób niemających od początku zdolności kredytowej, którym udzielono tych kredytów, ale załamanie się sytuacji u tych, którzy w ramach tzw. sekurytyzacji odkupili te wierzytelności i na ich podstawie wykreowali nowe kredyty. Zwiększanie akcji kredytowej wymagało zintensyfikowania biernych operacji bankowych. Szczególną rolę odegrała tu właśnie wspomniana sekurytyzacja. Dzięki technikom sekurytyzacyjnym, możliwe było emitowanie papierów wartościowych na bazie udzielanych kredytów (w tym kredytów drugiej jakości, czyli subprime), zwanych MBS (mortgage-backed securities). Ich sprzedaż pozwalała zarówno pozyskać dodatkowy kapitał, jak i przenieść część ryzyka kredytowego na nabywcę. MBS's zaczęto uwzględniać w konstrukcji strukturyzowanych papierów wartościowych, którymi głównie były zabezpieczone aktywami obligacje (tzw. CDOs - collateralized debt obligations). CDO's wykorzystywano również jako instrument zarządzania ryzykiem, a skala operacji tymi papierami była przy tym bardzo duża. Dodatkowo, nabywcy oraz emitenci MBS's i CDO's wykorzystywali do zabezpieczenia się przed ryzykiem kredytowym instrumenty pochodne, a mianowicie tzw. CDS (ang. credit default swap). Także w tym przypadku skala ich wykorzystania była znacząca i wyniosła w połowie 2008 roku 58 mld USD. Wykorzystując opisane instrumenty, kredytodawcy oraz inwestorzy w dużym stopniu ograniczali swe ryzyko dokonywanej operacji kredytowej (Jurek, Marszałek, 2010: 12-36).

Paul Krugman, znany z radykalnej krytyki neoliberalnej strategii rozwoju, odnosząc się do problemu przyczyn pojawienia się bieżącego kryzysu pisał: „Domy to domy; Amerykanie od bardzo dawna mieli w zwyczaju kupowanie nieruchomości za pożyczone pieniądze, ale trudno jest wytłumaczyć, dlaczego ktokolwiek miał uwierzyć, około 2003 roku, że podstawowe zasady przeprowadzania tego rodzaju transakcji zostały uchylone. $\mathrm{Z}$ doświadczenia wiadomo było, że kupujący domy nie powinni zaciagać kredytów hipotecznych, na których spłatę nie mogli sobie pozwolić. W ich interesie leżało natomiast odłożenie odpowiedniej sumy pieniędzy tak by przygotować się na spadek cen nieruchomości. Niskie stopy procentowe powinny wpłynąć na opłaty hipoteczne związane z wysokością kredytu, ale nic poza tym. W rzeczywistości doszło jednak do całkowitego odrzucenia tradycyjnych zasad. W pewnym stopniu było to wynikiem irracjonalnego entuzjazmu rozprzestrzeniającego się wśród pojedynczych rodzin, które obserwując ogromny wzrost cen domów, postanowiły zaistnieć na rynku i nie myśleć o przyszłych płatnościach. W większej mierze jednak u podłoża tego zjawiska leżały zmiany w sposobie udzielania kredytów. Kupujący otrzymywali pożyczki bez konieczności wpłaty lub po uiszczeniu niewielkiej zaliczki, dostając potem miesięczne rachunki znacznie przekraczające ich możliwości finansowe-zwłaszcza wówczas, gdy wyjściowo niska marża wzrosła. Nie wszystkie z tych wątpliwych kredytów można podciagnąć pod kategorię subprime: zachodzące zjawisko miało znacznie szersze znaczenie. Dotyczyło nie tylko ludzi o niskich dochodach lub małej grupy osób kupujących domy droższe niż mogły sobie pozwolić; fenomen obejmował szeroką grupe obywateli. [...] Dlaczego pożyczkodawcy obniżyli swoje standardy? Po pierwsze, wierzyli, że ceny nieruchomości będą nieustannie rosnąć. Tak długo, jak ceny te rosły, z punktu widzenia pożyczkodawcy nie miało znaczenia, czy osoba zaciagająca kredyt jest w stanie go spłacać: jeżeli raty okażą się za wysokie, klient zawsze może zarówno 
zaciaggnąć pożyczkę hipoteczną w celu uzyskania dodatkowej gotówki, jak i, w najgorszym wypadku, sprzedać dom i spłacić hipotekę. Po drugie, pożyczkodawcy nie zwracali uwagi na jakość swojego portfela kredytowego. Co więcej, sprzedawali kredyty ludziom, którzy nie rozumieli, co kupują. [...] W takim razie można spytać, dlaczego nie spróbować pójść na ugodę z obecnym właścicielem domu, zmniejszyć płacone przez niego raty i uchronić się od kosztów przejęcia nieruchomości? Cóż, po pierwsze, takie przedsięwzięcie też kosztuje i wymaga nakładu pracy. Po drugie, kredyty subprime nie były z reguły udzielane przez banki, które później je obsługiwały udzielali ich pośrednicy, którzy szybko sprzedawali zobowiązania instytucjom finansowym. Instytucje te dzieliły i łączyły kredyty w pakiety hipotek, które sprzedawały inwestorom pod postacią instrumentów sekurytyzacji opartych na długu (CDO). Rzeczywiste zarządzanie pożyczkami zostało pozostawione obsłudze kredytów, która nie miała ani możliwości, ani motywacji, by przeprowadzić ich restrukturyzację. Co więcej, złożoność inżynierii finansowej wspierającej pożyczki subprime, która pozostawiła hipoteki w rękach wielu inwestorów o zróżnicowanych uprawnieniach, piętrzyła prawne przeszkody na drodze do jakichkolwiek umorzeń kredytów. Wraz z pogarszaniem się sytuacji na rynku nieruchomości stawało się jasne, że pożyczkodawcy stracą dużą część środków, podobnie jak inwestorzy, którzy kupili zabezpieczone hipotekami papiery dłużne" (Krugman, 2012: 135-151).

Cytowany już Nouriel Roubini do komentarza tego dodawał: „Ten schemat powtarzał się w Stanach Zjednoczonych od 2000 r.: gdy znacząco wzrastały ceny domów, a wynagrodzenia pozostawały na tym samym poziomie, Amerykanie wykorzystywali swoje mieszkania jako zabezpieczenie następnych pożyczek, zaciaganych zwykle jako kredyty pod zastaw domu i będących formą spieniężenia majątku mieszkaniowego. Tak naprawdę ludzie traktowali swoje domy jak bankomaty. Dzięki temu, że domy nadal drożały, kredytobiorcy mogli zapożyczać się jeszcze bardziej i wykorzystywać jako dodatkowe zabezpieczenie nowych kredytów majątek już nabyty, modernizację domu albo nawet drugi dom. W ostatnim kwartale 2005 r. wartość spieniężonego w ten sposób majątku mieszkaniowego osiągnęła rekordowy poziom biliona dolarów w skali rocznej, pozwalając milionom gospodarstw domowych na życie ponad stan. W tym samym czasie stopa oszczędności gospodarstw domowych spadła do zera, by następnie, po raz pierwszy od czasów wielkiego kryzysu, osiagać negatywne wartości. Choć ta konsumpcja na kredyt nie mogła trwać bez końca, miała ona realne gospodarcze skutki: gospodarstwa domowe i firmy, kupując towary, napędzały wzrost gospodarczy. Sytuacja ta skłaniała do coraz bardziej ryzykownych przedsięwzięć gospodarczych, takich jak budowa osiedli mieszkaniowych na zupełnym odludziu. [...] W pewnym momencie ceny przestają rosnąć, zwykle taka sytuacja pojawia się wtedy, gdy podaż dóbr o zawyżonej wartości przewyższa popyt. Znika pewność, że ceny będą nadal rosnać, a przez to trudniej jest zaciagnąc kredyt. W Stanach Zjednoczonych, mechanizm ten zaczął się w momencie, gdy podaż na rynku nowych mieszkań przewyższyła popyt. Nadmiar domów wybudowanych w okresie boomu nałożył się na słabnący popyt - mocno zawyżone ceny i rosnące oprocentowanie kredytów hipotecznych sprawiły bowiem, że rynek nieruchomości przestał być dla Amerykanów atrakcyjny. Przewidywalne są również skutki takiego nagłego załamania koniunktury po okresie spekulacyjnego wzrostu. [...] Taki był rozwój wydarzeń w latach 2007-2008. Krach nastapił 
w chwili, gdy pojawiły się problemy ze spłatą kredytów hipotecznych zaciagniętych pod zakup domu, a co za tym idzie, gwałtownie spadła wycena papierów wartościowych zabezpieczonych tymi kredytami. Kryzys, który początkowo ogarnął system finansowy, rozprzestrzenił się na realną sferę gospodarki, wywołując wiele strat ubocznych" (Roubini).

W podobnym duchu przyczyny kryzysu diagnozowali cenieni polscy dziennikarze ekonomiczni W. Smoczyński i A. Lubowski. Pierwszy z nich pisał: „Amerykańska mania hipoteczna narodziła się w 2000 r. Po krachu spółek internetowych kapitał z Wall Street ewakuował się na rynek nieruchomości, powodując zwyżkę cen domów. Ale nie byłoby największego boomu budowlanego historii USA, gdyby nie szef Rezerwy Federalnej Alan Greenspan. Z obawy przed pogłębieniem recesji po zamachach na WTC w 2001 r. Fed zaczął ciać stopy procentowe, czyli koszt kredytu. Gdy skończył pieniądze leżały praktycznie na ulicy, a Amerykanie, zachęceni przez rząd wizją społeczeństwa własności, w którym każdy miał prawo do własnego domu, ruszyli po kredyty hipoteczne. W ciagu kilku lat pod metropoliami wyrosły hektary prefabrykowanych przedmieść, a boom kredytowy obudził giełdę. Pomógł też konsumpcji - Amerykanie uwierzyli, że ich domy będą drożeć w nieskończoność, i zaczęli brać pod ich zastaw kolejne kredyty. Na samochód, na wakacje, na dom dla dzieci. Bańka powinna była pęknąc latem 2005 r., gdy w USA skończyli się wiarygodni kredytobiorcy. Ale banki chciały przedłużyć dobrą passę i zaczęły oferować pożyczki klientom bez zdolności kredytowej. W 2006 r. pożyczki o wysokim ryzyku niespłacenia, słynne subprime, stanowiły już $20 \%$ nowych hipotek. Aby się zabezpieczyć, banki sięgnęły po inżynierię finansową - zaczęły przepakowywać ryzykowne kredyty w tzw. skolateralizowane obligacje dłużne (ang. collateralized debt obligation - CDO). Mało kto rozumiał ich konstrukcję, ale spece z Wall Street zapewniali, że CDO są nie tylko opłacalne, ale i całkowicie bezpieczne. Po nowy produkt ustawiła się kolejka banków i funduszy, chcących zarobić na dogrywce kredytowego boomu. Nikt nie pomyślał, że rozproszone ryzyko może zamienić się w równie rozproszone i trudne do oszacowania straty. Sektorem finansów zawładnęło szaleństwo tłumów. Pod koniec 2006 r. nadwyżka pustych domów była na tyle duża, że ceny ruszyły w dół, raty kredytów w górę, a po przedmieściach zaczęła toczyć się kula niewypłacalności. [...] Inaczej niż przy bańce internetowej, tym razem kryzys błyskawicznie przeniósł się na realną gospodarkę. Zapaść Wall Street sparaliżowała wielkie korporacje, odcinając je od kapitału, nieufność na rynku międzybankowym wywołała globalną suszę kredytową. Niedobór kredytu zdusił handel światowy, a stąd był już tylko krok do globalnej recesji”" (Smoczyński, Bez, 2012; Smoczyński, Byt, 2012; Smoczyński, Świat, 2012).

Z kolei A. Lubowski, ekonomista i felietonista, autor książki Kontuzjowane mocarstwo. Siła i słabości Ameryki podkreślał, że kryzys był wynikiem nadmiernego zadłużenia, głównie amerykańskiego konsumenta i banków. Autor ten dowodzi, że przez całe dekady miliony amerykańskich gospodarstw domowych korzystały z pożyczek konsumpcyjnych pod zastaw nieruchomości. W miarę jak rosły ceny domów, przeciętny Amerykanin czuł się coraz bogatszy i wydawał więcej niż zarabiał. Zadłużenie gospodarstw domowych w chwili, gdy nadszedł kryzys wyniosło 13,8 bln, co stanowiło 98\% PKB, a zadłużenie amerykańskiego sektora finansowego na koniec 2008 r. wyniosło 17,1 bln dol., czyli $121 \%$ PKB. Podczas gdy od 2008 r. poziom zadłużenia ame- 
rykańskich gospodarstw domowych i banków nieco się obniżył, to dług rządu nadal szybko rósł. Gospodarka amerykańska w trakcie życia zaledwie jednego pokolenia z największego wierzyciela przekształciła się w największego na świecie dłużnika. $\mathrm{Na}$ koniec marca 2010 r. wartość obligacji rządu amerykańskiego u zagranicznych wierzycieli wynosiła niemal 4 bln USD.

W podobnym duchu przyczyny i przebieg kryzysu diagnozuje W. Nawrot w pracy Globalny kryzys finansowy XXI wieku. Przyczyny, przebieg, skutki, prognozy. Zauważa, że ceny nieruchomości w USA zaczęły spadać w 2006 r. Na przełomie 2007 i 2008 r. nie było już wątpliwości, że rynek nieruchomości się załamał. Próbując sprzedać nieruchomości, podmioty te przyspieszyły jednak proces obniżki ich cen, co wywoływało dalszy spadek wartości przyjętych zabezpieczeń i potęgowało problemy instytucji finansowych. Sytuację znacznie pogorszyło stosowanie na szeroką skalę inżynierii finansowej. Skala problemów z papierami wyemitowanymi na podstawie kredytów subprime okazała się ogromna. Już w połowie 2007 r. CDO, w sytuacji spadku cen na rynku nieruchomości i rosnącego wskaźnika niespłacanych kredytów subprime, okazały się papierami bez pokrycia. Pojawiły się przy tym problemy z ich wyceną, gdyż obrót nimi praktycznie zamarł. Tworzone przez banki fundusze dzięki wykorzystaniu instrumentów typu CDO, przekształcały te wierzytelności substandardowe w instrumenty o wysokim ratingu inwestycyjnym. Banki sprzedawały innym instytucjom finansowym wierzytelności związane z udzielanymi kredytami albo traktowały je jako zastaw pod kolejne kredyty, co zwiększało zakres infekcji w całym systemie finansowym. Niewiarygodny kredyt stawał się podstawą kolejnego niewiarygodnego kredytu, który ulokowany w innym banku staje się podstawą kolejnego kredytu itd. W konsekwencji wystąpił chroniczny kryzys płynności na międzynarodowych rynkach pieniężnych, gdyż nastąiła utrata wzajemnego zaufania ich uczestników. Kryzys ten stał się kryzysem zaufania, ponieważ instytucje finansowe obawiały się, że jeżeli pożyczą środki innej instytucji finansowej, a ta następnie upadnie utracą je. W pierwszej kolejności ofiarami kryzysu stały się wielkie amerykańskie banki inwestycyjne nieposiadające własnej bazy depozytowej i silnie uzależnione od finansowania zewnętrznego. Następne były fundusze hedgingowe oraz banki będące właścicielami funduszy sekurytyzacyjnych (Nawrot, 2009: 22-57).

W lutym 2007 r. gorsze od oczekiwanych wyniki finansowe ogłosił trzeci co do wielkości w świecie bank $H S B C$. Powodem był wzrost udziału kredytów zagrożonych (ang. subprime mortgages), których wartość okazała się pięciokrotnie wyższa od przewidywań analityków. Niższe od oczekiwanych wyniki finansowe zaprezentował też główny w USA kredytodawca w segmencie ryzykownych kredytów hipotecznych New Century Financial. Na wartości zaczęły też tracić akcje m.in. JPMorgan, Lehman Brothers, Wells Fargo oraz kredytodawców w segmencie subprime: American Home Mortgage Investments oraz Accredited Home Lenders. W sierpniu 2007 r. Bear Stearns złożył wniosek o ochronę przed wierzycielami dla dwóch swoich funduszy z nadmierną ekspozycją na rynek subprime mortgages. W tym samym czasie trzy niemieckie banki odkryły przed rynkiem finansowym poważne problemy nadmiernej ekspozycji kapitałowej na amerykański rynek subprime mortgages. IKB Deutsche Industriebank, Sachsem $L B$ oraz West $L B$ stanęły na progu upadłości. Ponadto trzy należące do renomowanego francuskiego banku $B N P$ Paribas i warte 2 mld euro fundusze inwestycyj- 
ne: Parvest Dynamie ABS, BNP Paribas ABS Eonia oraz BNP Paribas ABS Euribor, ulokowały $700 \mathrm{mln}$ euro, czyli $30 \%$ swego portfela inwestycyjnego, w instrumenty zbudowane w oparciu o amerykański rynek subprime mortgages. Problemy dotknęły też Northern Rock jednego z największych kredytodawców hipotecznych Wielkiej Brytanii. W konsekwencji bank stanął na progu upadłości, a następnie został znacjonalizowany, pomimo tego, że nie miał ekspozycji na amerykański rynek subprime. Był on nadmiernie uzależniony od krótkoterminowego finansowania płynącego z rynku międzybankowego ( $70 \%$ ogółu źródeł finansowania), które praktycznie zostało zamrożone ze względu na brak zaufania wynikający z tego, iż banki podejrzewały inne banki o ekspozycję na subprime morgages. We wrześniu 2008 r. Lehman Brothers Holdings Inc., czwarty co do wielkości bank inwestycyjny w USA, stał się niewypłacalny i wkrótce upadł w wyniku fiaska trwających rozmów w Fed pomiędzy najważniejszymi bankami na Wall Street. Merrill Lynch został przejęty przez Bank of America, a American International Group Inc. (AIG), amerykański gigant ubezpieczeniowy, który zakupując CDS na setki miliardów USD ubezpieczał ryzyko kredytowe swoich inwestycji w aktywa dłużne, poprosił Fed o pomoc finansową. Bankructwo Lehman Brothers z aktywami o wartości przekraczającej 600 mld USD stało się największym bankructwem w historii Wall Street. Po problemach Lehman Brothers oraz $A I G$ rynek zaczął spoglądać z nieufnością na kolejne banki, które mogły być potencjalnie narażone na kłopoty finansowe. W szczególności na Goldman Sachs oraz Morgan Stanley, pomimo że oba banki nie miały istotnej ekspozycji na amerykański rynek subprime (ibidem).

Tak więc szybko okazało się, że poważne problemy miały również instytucje, także spoza Stanów Zjednoczonych, które nie udzielały kredytów hipotecznych, ale inwestowały w związane z nimi instrumenty finansowe. Spowodowało to spadek kursów akcji na światowych giełdach, a dodatkowo stopniowo zaczął załamywać się rynek kapitałowy. $\mathrm{W}$ wyniku spadku zaufania na rynku, $\mathrm{u}$ wielu instytucji finansowych $\mathrm{w}$ świecie pojawiły się problemy z płynnością. 15 września 2008 r., kiedy upadłość ogłosił bank inwestycyjny Lehman Brothers uważa się za „oficjalny” początek światowego kryzysu finansowego 2008+ (ang. global financial crisis). W marcu 2009 r. przewodniczący Fed Ben Bernanke straty sektora finansowego oceniał na 1,5 bln USD. W czerwcu 2009 r. straty szacowano już na ponad 2 bln USD, a Nouriel Roubini wyliczał je na poziomie 3,6 bln USD (Wspótczesny, 2009: 17-37; Nawrot, 2009: 22-57).

Raghuram G. Rajan uznany amerykański ekonomista, hinduskiego pochodzenia, zauważył przy tym, że dawniej, kiedy jakiś bank udzielał kredytu hipotecznego, który zamierzał trzymać w księgach, wzywał do siebie kandydata na pożyczkobiorce. Doradca kredytowy przeprowadzał z nim rozmowę, żądał dokumentów potwierdzających zatrudnienie oraz dochody i oceniał, czy kandydat jest w stanie unieść ciężar zadłużenia $i$ czy jest wiarygodny. Ocena taka nie opierała się wyłącznie na suchych faktach. Obejmowała też takie elementy, jak to, czy kandydat jest dobrze wychowany, czysto ubrany, czy można mu zaufać i czy jest w stanie utrzymać pracę. Bez wątpienia pewną rolę odgrywały też wskazówki dotyczące kultury osobistej kandydata. Dzięki kontaktom osobistym ocena kredytowa zdawała mieć większą wartość, tym bardziej że doradca miał też świadomość, że klient „będzie mu ciążył na sumieniu”, jeśli namówi go na kupno domu, na który go nie stać. Lecz kiedy banki inwestycyjne zaczęły łączyć kredyty hipo- 
teczne w gigantyczne pakiety, bezpośrednia rozmowa z potencjalnym kredytobiorca stawała się coraz mniej istotnym elementem oceny. Dla banków inwestycyjnych i agencji ratingowych znaczenie miała wyłącznie nieliczbowa ocena zdolności kredytowej kredytobiorcy oraz wielkość pożyczki względem wartości domu. Były to pewne, sprawdzalne informacje, łatwe do przetworzenia, które rzekomo podsumowywały ocenę kredytową. W związku z tym pośrednicy, którzy inicjowali kredyty, niczego innego nie brali pod uwagę. A kiedy rynek ,rozgrzał się do czerwoności”, przestali nawet sprawdzać zatrudnienie czy dochody klienta. Potwierdza to przykład New Century Financial, firmy założonej w 1995 r., która w pewnym momencie stała się drugim co do wielkości kredytodawcą na rynku subprime w USA, udzielając w 2006 r. kredytów hipotecznych na sumę blisko 60 mld dolarów. Według Roberta M. Harta, zastępcy prokuratora generalnego stanu Ohio w czasie boomu mieszkaniowego „kredyt sprzedałaby nawet psu" (Rajan, 2012: 174-180, 209-217).

Ostatnie lata dowiodły, że procesy finansowe przestały być odbiciem realnych procesów zachodzących w gospodarce. Jak pisze Chris Harman kryzys nastąpił po ćwierćwieczu, w czasie którego sektor finansowy rozrósł się na ogromną skalę i zaczął odgrywać w systemie nieznaną dotąd rolę. Według giełdowej wyceny, wartość amerykańskich instytucji finansowych stanowiła w 2004 r. 29\% wartości niefinansowych, co oznaczało, że w ciągu dwudziestu pięciu lat wzrosła czterokrotnie. Stosunek zysków korporacji finansowych do zysków korporacji niefinansowych wzrósł z około 6\% na początku lat 50. i 60. minionego wieku do około 26\% w $2001 \mathrm{r}$. Globalne aktywa finansowe szacowano w 2005 r. na 316\% rocznego produktu światowego, podczas gdy w 1980 r. stanowiły one tylko 109\%. Zadłużenie gospodarstw domowych w Stanach Zjednoczonych równało się w 2006 r. 127\% całkowitego dochodu osobistego w porównaniu z zaledwie $36 \%$ w 1952 r., około 60\% pod koniec lat 60 . i 100\% w 2000 r. (Harman, 2011: 404-406).

Inną istotną przyczyną wrażliwości obecnego systemu finansowego na zjawiska kryzysowe są zmiany w strukturze finansowania przedsiębiorstw i gospodarstw domowych. Finansowanie wewnętrzne (głównie z własnych zasobów i oszczędności) zostało zastąpione przez finansowanie zewnętrzne, z reguły przy użyciu tzw. dźwigni/lewara (ang. leverage). Na problem ten zwraca uwagę Tomasz Gruszecki w pracy Świat na długu. W jego opinii, nowe instrumenty finansowe, zwłaszcza sekurytyzacja oraz obligacje zabezpieczone aktywami i kredytem, a także wprowadzenie takich instrumentów, jak CDS's, pozornie zabezpieczających coraz większą liczbę instrumentów finansowych opartych na kredytach, znacznie zwiększyły stopień używanej dźwigni do niespotykanych przedtem proporcji (np. 1:30). Wiązało się to ze znacznym zwiększeniem ryzyka podejmowanego przez kredytodawców, kredytobiorców i inwestorów oraz skłonności do podejmowania ryzyka. Zmianie uległa też struktura zobowiązań, na rzecz wzrostu znaczenia krótkoterminowych w stosunku do długoterminowych. Jednocześnie w wyniku koncentracji powstały wielkie instytucje finansowe typu banki, dysponujące aktywami nieraz kilkakrotnie przewyższającymi wielkość PKB państw, w których są ulokowane, często ,zbyt duże, żeby upaść” (ang. too big too fall), poważnie narażone na zakłócenia w stałym dopływie kapitału. Dodać należy, że przez światowy rynek pieniężny przepływa obecnie ponad 4 bln USD dziennie (Gruszecki, 2012: 170-175). 
Problemem była też swoista i pytanie na ile celowa, dezinformacja społeczna. Kiedy na początku 2007 r. w Stanach Zjednoczonych pojawiły się pierwsze oznaki kryzysu na rynku nieruchomości i kredytów hipotecznych wysokiego ryzyka, Przewodniczący Fed Ben Bernanke otwarcie poinformował Kongres, że: ,Wszystko jednak wskazuje na to, że w ostatnim czasie udało nam się zdecydowanie ograniczyć wpływ, jaki na resztę gospodarki i rynki finansowe wywierały problemy związane z kredytami złej jakości”. Latem 2007 r. Sekretarz skarbu Henry Paulson bagatelizował niebezpieczeństwo krachu spowodowanego tego rodzaju kredytami, oznajmiając: „nie sądzę, by stanowiły one jakiekolwiek zagrożenie dla gospodarki”. W maju 2008 r., po upadku banku Bear Stearns, stwierdził z kolei: „Spodziewam się, że w przyszłości rynki finansowe będą mniej zależne od obecnego zamętu, a bardziej od koniunktury gospodarczej, zwłaszcza od poprawy sytuacji na rynku mieszkaniowym". Natomiast po upadku Fannie Mae i Freddie Mac, giełdowy autorytet i ceniony komentator branży finansowej Donald Luskin, w komentarzu zamieszczonym we wrześniu 2008 r. w „Washington Post” oznajmił, że ,w najbliższym czasie Stany Zjednoczone czeka ożywienie gospodarcze". Wieloma wypowiedziami lekceważąco odnoszącymi się do przyczyn i skutków bieżącego kryzysu ,zasłynął” też znany amerykański ekonomista Frederic Mishkin z Columbia Business School (Roubini, Mihm, 2011: 117-132).

Na sygnalizowany wcześniej problem kryzysu zaufania uwagę zwrócił też W. Orłowski. Według tego ekonomisty bieżący kryzys nie tyle polega na określonej skali spadku produkcji lub cen akcji, lecz na trwałym, powszechnym, zazwyczaj bardzo gwałtownym, załamaniu zaufania wszystkich podmiotów operujących na rynku: klientów do banków, banków do innych banków, banków do firm, inwestorów do rządów, pracowników do pracodawców, ludzi do polityki gospodarczej rządu. Groźba bankructwa jakiegokolwiek dużego banku powoduje, że rynek międzybankowy zostaje całkowicie sparaliżowany, z dramatycznymi konsekwencjami dla reszty gospodarki. Podobne efekty może przynieść groźba niewypłacalności któregoś z państw, wywołując rynkową panikę i lawinę kolejnych niewypłacalności. „Kryzys przychodził etapami, wysyłając wiele sygnałów ostrzegawczych, niestety, generalnie zlekceważonych lub źle zinterpretowanych. Najpierw, w latach 2001-2002 załamały się ceny akcji firm internetowych (tzw. dot.com). Był to pierwszy wyraźny sygnał mówiący, że obserwowany od początku lat 90 . niezwykły boom na giełdach nie ma wcale mocnych podstaw ekonomicznych, że jest raczej spekulacyjną bańką. Panika jednak po jakimś czasie się skończyła, a gdy amerykański bank centralny obniżył cenę kredytu, inwestorzy wrócili na parkiet. W ciągu kolejnych pięciu lat ceny akcji znów poszły w górę: w USA dwukrotnie, na wschodzących rynkach nawet 3-4 razy. Kiedy z kolei latem 2007 r. pojawiły się pierwsze informacje o dużych stratach, jakie mogły przynieść inwestycje w obligacje oparte na dochodach z amerykańskich kredytów hipotecznych obniżonej jakości (subprime), rynek zareagował na nie silnym tąpnięciem. Po siedmiu tłustych latach, kiedy ceny nieruchomości w USA rosły w średnim tempie 14\% rocznie, teraz zaczęły równie gwałtownie spadać. Uczestnicy rynku musieli się orientować, że w tym czasie wyemitowano warte biliony dolarów obligacje, których głównym filarem było właśnie założenie o stałym wzroście cen domów. Ponownie jednak panika minęła, a na giełdy powrócił spokój. Tym razem jednak było to już ostatnie ostrzeżenie. Szybko wyliczono, że straty finansowe wywołane załamaniem się cen na amerykańskim rynku 
nieruchomości muszą sięgać co najmniej biliona dolarów, ale największe banki świata przyznawały się do strat z tego tytułu stanowiących tylko drobny ułamek tej kwoty. Wybuchały pierwsze objawy paniki związanej z zagrożeniem upadkiem kolejnych banków hipotecznych, a rząd USA musiał przejąć zarządzanie nad dwiema gigantycznymi korporacjami specjalizującymi się w obsłudze rynku hipotecznego. Pełnej skali załamanie przyszło jednak dopiero 15 września 2008 r., kiedy bank Lehman Brothers - jeden z pięciu największych banków inwestycyjnych na Wall Street - nagle ogłosił, że jest bankrutem. Dopiero ta katastrofa odsłoniła prawdziwą skalę zagrożenia. Okazało się, że straty związane z załamaniem się cen na rynkach nieruchomości idą w biliony dolarów, grożąc wielu globalnym bankom upadkiem. W efekcie natomiast doszło do niemal całkowitego paraliżu międzybankowego. Dramatyczna sytuacja, w której znalazł się globalny sektor bankowy, doprowadziła do gwałtownego załamania się kursów akcji na światowych giełdach. W ciagu miesiąca od upadku banku Lehman Brothers indeksy głównych giełd w krajach rozwiniętych spadły o 25\%, a na wschodzących rynkach o 50\%. Świadomość, że w pierwszej kolejności trzeba regularnie spłacać kredyty hipoteczne, doprowadziła do silnego ograniczenia wydatków konsumpcyjnych, wciagając światową gospodarkę w najpotężniejszą recesję od lat 30. minionego wieku. Spadający popyt w krajach najzamożniejszych, a w ślad za tym spadające nakłady inwestycyjne firm, zaowocowały znacznym spadkiem zakupów importowych i inwestycji zagranicznych dokonywanych w krajach rozwijających się. W ten właśnie sposób recesja błyskawicznie rozprzestrzeniła się na cały świat. Z drugiej strony, gwałtowny spadek zaufania na rynkach finansowych zaowocował gwałtownym odcięciem krajów rozwijających się od dostępu do prywatnego kapitału. W ślad za kryzysem finansowym przyszły więc jego efekty wtórne. Spadła produkcja i silnie wzrosło bezrobocie, dramatycznie pogorszyła się dostępność kredytu dla firm. Na skraju bankructwa stanęły wielkie banki i korporacje przemysłowe, w oczach zaczęło rosnąć zadłużenie publiczne. Na początku 2010 r. pojawiły się obawy, że nadmierny poziom zadłużenia może doprowadzić do niewypłacalności państw - ich pierwszą ofiarą padły kraje śródziemnomorskie, należące do Unii Europejskiej. Kryzys pokazał swoje pełne oblicze" - podkreślał cytowany autor (Globalizacja, 2010: 45-53).

Joseph E. Stiglitz na pytanie: które przełomowe decyzje doprowadziły do kryzysu? odpowiada wprost. Błąd pierwszy to sytuacja z roku 1987, kiedy administracja Ronalda Reagana postanowiła pozbawić Paula Volckera stanowiska prezesa Rady Rezerwy Federalnej i mianować zamiast niego Alana Greenspana. P. Volcker zdawał sobie także sprawę z nieodzowności regulowania rynków finansowych, a Greenspan takiej konieczności już nie widział i to za jego prezesury doszło do pęknięcia nie jednej, lecz dwóch baniek na rynku (dot.com i nieruchomości).

Błąd drugi to sytuacja z listopada 1999 r., kiedy Kongres zniósł ustawę Glass-Steagall Act, co było zwieńczeniem lobbingu firm z branży bankowej i usług finansowych (przeznaczyły na to 300 milionów dolarów) oraz działań podejmowanych w Kongresie przez senatora Phila Gramma. Ustawa ta długo narzucała rozdział banków komercyjnych (które udzielają pożyczek) od banków inwestycyjnych (przygotowujących sprzedaż obligacji i akcji). Gwarantowała, że banki komercyjne nie będą podejmować nadmiernego ryzyka, lecz ostrożnie zarządzać pieniędzmi depozytariuszy. Banki inwestycyjne natomiast tradycyjnie zarządzały pieniędzmi klientów zamożniejszych, a więc 
takich, którzy mogą podjać większe ryzyko, aby przez to uzyskać większe zyski. Gdy w następstwie zniesienia wskazanej ustawy banki inwestycyjne i komercyjne mogły się łączyć, dominujące okazały się bardziej ryzykowne zasady obowiązujące w bankowości inwestycyjnej.

Błąd trzeci stanowiły ulgi podatkowe wprowadzone w życie za prezydentury George’a W. Busha. Pierwsze z 7 czerwca 2001 r., a kolejne dwa lata później. Prezydent i jego doradcy sądzili, że ulgi podatkowe, szczególnie przyznawane korporacjom i Amerykanom osiagającym największe dochody, zdynamizują wzrost gospodarczy i stworzą dodatkowe miejsca pracy. Niestety tak się nie stało i faktyczne symulowanie wzrostu gospodarczego pozostawiono Radzie Rezerwy Federalnej, która wprowadziła bezprecedensowo niskie stopy procentowe i zapewniła wielką podaż pieniądza. Przez zapewnienie wielkiej dostępności gotówki pieniądze można było bez trudu uzyskać na rynkach kredytów hipotecznych, przyznawanych nawet tym, którzy normalnie nie mogliby się ubiegać o pożyczki. Do kryzysu przyczyniła się też, choć w odmienny sposób, redukcja stawki opodatkowania zysków kapitałowych. Ci, którzy spekulowali (grali na giełdzie) i wygrywali, płacili niższe podatki niż ciężko pracujący amerykańscy pracownicy. Podważało to wartość pracy jako takiej.

Błędem czwartym, w opinii cytowanego autora, było stworzenie niezdrowych zasad funkcjonowania agencji ratingowych. Agencje, takie jak Moodys czy Standard\&Poors, otrzymywały pieniądze od osób, które następnie miały oceniać. Dlatego też miały wszelkie powody, aby ocenianym przedsiębiorstwom wystawiać wysokie oceny. Toksyczne aktywa bankowe zabezpieczone kredytami hipotecznymi, zasługiwały na ocenę „niedostateczny”, tymczasem często zyskiwały najwyższe ratingi.

Ostatnim, piątym błędem była reakcja administracji amerykańskiej na kryzys, czyli przyjęcie pakietu ratunkowego z 3 października 2008 r. (tzw. pakiet Paulsona). Zdaniem J. E. Stiglitza, gdyby administracja rzeczywiście chciała przywrócić zaufanie do systemu finansowego, zaczęłaby od rozwiązywania problemów fundamentalnych, czyli niewłaściwych struktur motywacyjnych w instytucjach finansowych i nieodpowiednich regulacji. Tymczasem niektóre firmy i instytucje uratowano (Bear Stearns, AIG, Fannie Mae i Freddie Mac). Innym, takim jak Lehman Brothers pozwolono upaść. Inaczej mówiąc, niektórym udziałowcom coś zapewniono, innym nie, potęgując niezrozumienie i chaos na rynku (Carter 2011/2012: 205-215).

Większość zaprezentowanych argumentów syntetycznie i przyznać należy, że w bardzo wciagającej widza formie ujęte zostały w godnym polecenia, oskarowym filmie dokumentalnym w reżyserii Charlesa Fergusona Inside Job (pol. Szwindel: Anatomia kryzysu).

Prezentowana interpretacja przyczyn pojawienia się kryzysu i akcenty, jakie zostały w niej położone, nie jest - co wyraźnie należy podkreślić - jedyną. Inaczej przebieg kryzysu interpretują zwolennicy doktryny neoliberalnej, z Leszkiem Balcerowiczem na czele. We wstępie do książki Johna B. Taylora, Zrozumieć kryzys finansowy. Przyczyny, skutki, interpretacje, jeden z najbardziej znanych i cenionych polskich ekonomistów stwierdza: „Jest prawdą że w sektorze finansowym, najpierw Stanów Zjednoczonych, a potem wielu krajów rozwiniętych, wystapiły poważne zaburzenia. Jednakże głębsze przyczyny tych zaburzeń nie musiały (choć mogły) tkwić w tym sektorze, lecz w warunkach jego działania. Nie należy zapominać, że duża część owego sektora, zwłaszcza 
banki, działa w otoczeniu silnie kształtowanym przez władzę publiczną (rządy, parlamenty, banki centralne) - przez politykę pieniężną, nadzorczą, fiskalną i regulacyjną. Do myślenia powinien też dawać fakt, że największe zaburzenia wybuchły w tych częściach sektora finansowego, których warunki działania były i są najsilniej ukształtowane przez władze publiczne. Etatystyczny przekaz związany z obecnym kryzysem ma słabe oparcie w fachowych opracowaniach analitycznych. Wiele z nich pokazuje, jak błędy w polityce państw przyczyniły się do obecnego kryzysu" (Taylor, 2010: 5-15).

W dalszej części komentarza L. Balcerowicz zauważa, że John B. Taylor, profesor ekonomii na Uniwersytecie Stanforda i jeden z największych światowych autorytetów $\mathrm{w}$ analizie w dziedzinie makroekonomii, a szczególnie podstaw polityki pieniężnej, dowodzi, że to nadmierne obniżenie stóp procentowych przez Fed po 2001 r. wywołało przyspieszony wzrost kredytu, który z kolei przyczynił się do nadmiernego wzrostu cen i bańki mieszkaniowej. Jej pęknięcie w 2007 r. było detonatorem kryzysu finansowego. W opinii J. B. Taylora zbyt niskie stopy procentowe w Stanach Zjednoczonych tworzyły presję na banki centralne w innych państwach i regionach, w tym w strefie euro, aby i tam nadmiernie obniżać koszt kredytu. Główny mechanizm ekonomiczny owej presji polegał na tym, że obniżka stóp procentowych w tak wielkiej gospodarce jak Stany Zjednoczone powoduje, że kapitał finansowy zwiększa swój napływ do innych państw, a to z kolei może prowadzić do silnej aprecjacji ich walut. Aby uniknąć tego zagrożenia, inne banki często również obniżają stopy procentowe - uruchamiając przyspieszony wzrost kredytu na swoich rynkach. Pokazuje to, że globalne problemy nie muszą pojawiać się jednocześnie i równomiernie we wszystkich państwach świata, a mogą mieć swój początek w tych, które są globalnie istotne, następnie rozprzestrzeniając się na inne (ibidem).

Godzien polecenia jest też wywiad jakiego John. B. Taylor udzielił Andrzejowi Lubowskiemu, zatytułowany $Z$ dama pik $w$ rękawie i zamieszczony na portalu POLITYKA.PL. W podobnym duchu pisze też Philip Booth profesor ekonomii na City University w Londynie i dyrektor ds. badań w Institute of Economic Affairs. Twierdzi on, że błędne jest przekonanie, iż kryzys 2008 r. został spowodowany przez niepodlegających nadzorowi i kontroli bankierów, którzy kierowani byli chciwością, żądzą zysku i pogonią za premiami. Sugeruje, że na rynkach finansowych wyraźny był pewien trend myślenia, który rząd amerykański, czy szerzej regulatorzy rynku, wspierali i pobudzali. Politykę tą opisuje on jako skrzywienie na korzyść ubogich. Początkowo wynikała ona z przekonania ówczesnego prezydenta Billa Clintona, iż biedniejsze części społeczeństwa amerykańskiego mogą się włączyć w główny nurt życia, jeżeli otrzymają przyzwoite miejsce do zamieszkania. Stąd pojawiła się polityczna presja na działania o charakterze gospodarczym czy finansowym. P. Booth przywołuje przy tym statystyki. W Stanach Zjednoczonych główna stopa procentowa na rynku rezerw banków komercyjnych (ang. Fed Funds Rate) została obniżona w 2001 r. z 6,25\% do $1,75 \%$. Z czasem nastąpiły dalsze obniżki i do połowy $2004 \mathrm{r}$. utrzymywała się ona na poziomie $1 \%$. Właściwie przez dwa i pół roku, między 2002 i 2004, realna stopa procentowa była ujemna. Ortodoksja, czyli standardowa praktyka, w latach 2001-2005 nakazywałaby utrzymanie poziomu stóp od 2\% do 5\% (Platon, 2010: 14-29).

Poważnym błędem w opinii neoliberalnie nastawionych badaczy i komentatorów było więc uchwalenie w USA aktów prawnych umożliwiających, czy wręcz zachę- 
cających do udzielania kredytów grupom społecznym o bardzo niskich dochodach. Złym pomysłem było powołanie do życia i dotowanie instytucji temu służących z $\mathrm{Fe}$ deralnym Narodowym Stowarzyszeniem Kredytów Hipotecznych (Fannie Mae) i Federalna Korporacja Kredytów na Budowe Domów (Freddie Mac) na czele. Ogólnie przyczyny kryzysu tkwią więc w ich opinii w sferze wadliwej polityki rządów i banków centralnych, a nie w systemowych niedoskonałościach rynków finansowych (Gospodarka, 2010: 55-74).

Bez względu jednak na kontrowersje dotyczące tego kto lub co ponosi największą winę za pojawienie się bieżącego kryzysu finansowego, mechanizm jego powstania (w ujęciu schematycznym) przejrzyście można wyjaśnić w oparciu o teoretyczną koncepcję Charlesa Kindlebergera (wybitnego specjalisty od kryzysów finansowych), który przedstawił wzorzec baniek spekulacyjnych. Według niego kryzys jest procesem składającym się z pięciu następujących faz:

- powstanie nowych propozycji,

- ekspansja kredytu,

- mania spekulacji,

- pojawienie się niebezpiecznej sytuacji,

- załamanie (krach) i panika.

Nowa propozycja w przypadku obecnego kryzysu była sekurytyzacja kredytów mieszkaniowych poprzez nowy instrument finansowy znany jako zobowiązanie zabezpieczone długiem (CDO - Collateralized Debt Obligation). Ekspansja kredytu stanowi drugą fazę bańki spekulacyjnej. Do ekspansji tej przyczyniła się łagodna polityka pieniężna prowadzona przez System Rezerwy Federalnej $(\mathrm{Fed})$, który począwszy od stycznia $2001 \mathrm{r}$. obniżył bazowe stopy procentowe z 6\% do najniższego od czasów II wojny światowej poziomu $0-0,25 \%$. Spowodowało to ogromny wzrost kredytów i zbyt szybkie zadłużanie się podmiotów gospodarczych, zwłaszcza gospodarstw domowych. Kombinacja nadzwyczajnie niskich stóp procentowych i długookresowych kredytów zaowocowała przystępnymi ratami miesięcznymi, nawet gdy ceny nieruchomości rosły. Gdy te raty były nadal zbyt wysokie dla klientów o niskich dochodach wynajdowano środki, aby jeszcze bardziej obniżyć wstępne płatności. Zwykle przyjmowało to postać kredytów hipotecznych o zmiennej stopie oprocentowania, z niskimi, zachęcającymi stopami procentowymi i klauzulą resetu po wcześniej ustalonym okresie (zwykle od 3 do 5 lat).Wartość wielu kredytów hipotecznych subprime wyniosła 100\% szacowanej wartości domów. Kredytów hipotecznych typu subprime często udzielano klientom określanym jako NINJA (ang. no income, no job, no assets), a więc osobom bez dochodów, pracy i możliwości dania bankowi zastawu. Jako zastaw potraktowano oczekiwany wzrost wartości domów kupionych na kredyt. Ekspansja kredytu prowadziła do powstania swoistej manii spekulacji. Wielu właścicieli domów zaczęło postrzegać wzrost wartości swoich posiadłości jako proces naturalny i długotrwały. Wykorzystano niskie stopy procentowe do refinansowania zaciagniętych kredytów i uzyskiwania wartości gotówkowej z domów. Był to sposób na podtrzymanie lub podniesienie poziomu konsumpcji (wartość nowo zaciągniętych kredytów hipotecznych stanowiła aż 69,4\% PKB Stanów Zjednoczonych Ameryki w 2005 r.). W określonym momencie narastania bańki spekulacyjnej następuje gwałtowna zmiana na rynkach finansowych, którą określa się mianem niebezpiecznej sytuacji. Bańka 
kredytów hipotecznych została po raz pierwszy „nakłuta” w 2006 r. w Kalifornii, Arizonie i na Florydzie, czyli w regionach najbardziej intensywnego udzielania kredytów subprime. Kredytobiorcy, których kondycja finansowa była uzależniona od szybkiego wzrostu cen domów i niskich stóp procentowych zostali nagle skonfrontowani ze spadającymi cenami i rosnącymi ratami kredytów. Końcową fazą w bańce spekulacyjnej jest załamanie i panika, sygnalizowane przez gwałtowną wyprzedaż aktywów. Pierwsze załamanie, które wstrząsnęło rynkiem miało miejsce w lipcu 2007 r. Implodowały wówczas dwa fundusze hedgingowe Bear Stearns, które posiadały prawie 10 mld dolarów w hipotecznych listach zastawnych (Współczesny, 2009: 84-99).

Równie interesująco przyczyny pojawienia się obecnego kryzysu wyjaśnione zostały w modelowym ujęciu H. M. Minsky'ego. Analizuje on zarówno zachowanie i zmiany zachowania się kredytobiorców, jak i banków w poszczególnych fazach. H. M. Minsky zakłada pięć faz tworzenia się bańki:

1) w fazie pierwszej (okresie wzrostu) ma miejsce wzrost optymizmu zarówno u inwestorów (kredytobiorców), jak i banków finansujących;

2) w fazie drugiej następuje u kredytobiorców ogólne podwyższenie prognoz rentowności w różnych obszarach inwestycji, a w sektorze banków tendencja do niedoszacowania ryzyka kredytowego;

3) w fazie trzeciej u kredytobiorców następuje wzrost skłonności do zadłużania. Dotyczy to nie tylko kredytów inwestycyjnych, ale i konsumpcyjnych (często zakupu nieruchomości). Inwestycje te mają charakter spekulacyjny - aktywa mające przynieść szybki zysk, a zwrot kredytu nastąpi dopiero po spieniężeniu inwestycji. W tym samym czasie banki znacznie obniżają ocenę ryzyka, pożyczając nawet tym podmiotom, które dotąd nie miały żadnej zdolności kredytowej;

4) w fazie czwartej do fali spekulacji wchodzą ci, którzy przedtem byli poza rynkiem. Wzrastająca cena aktywów będących przedmiotem spekulacji wciaga ich do gry o szybki zysk. Niedoświadczeni inwestorzy usiłują naśladować doświadczonych liderów, nadal kredytując spekulacyjne inwestycje;

5) faza ostatnia to pierwsze załamanie cen, stopniowa wyprzedaż, a w końcu masowe załamanie rynku i wyprzedaż aktywów na masową skalę. W konsekwencji kryzys przenosi się na cały rynek finansowy i następuje załamanie gospodarki realnej na dużą skalę. Towarzyszy temu powszechne zadłużenie i niemożliwość spłaty zaciagnniętych długów, ulokowanych $\mathrm{w}$ aktywach będących przedmiotem spekulacji (Gruszecki, 2012: 170-175).

Część autorów podkreśla przy tym, że przy ocenie przyczyn i skutków kryzysu istnieje groźba skupienia się jedynie na technicznych błędach, związanych z brakiem należytej kontroli i nadzoru nad rynkiem finansowym w USA i innych państwach w świecie, czy błędną polityką Fed i innych banków centralnych. Tymczasem - w ich opinii - źródła zjawisk kryzysowych są głębsze. Cytowany już Władysław Szymański zauważa, że niewątpliwym skutkiem procesu globalizacji, a zwłaszcza uwolnienia rynków kapitałowych, z jednej strony jest ogromne rozszerzenie zestawu dostępnych dla inwestorów aktywów finansowych, a z drugiej, niepomierne powiększenie możliwości ich lokowania. Jednocześnie zwiększyły się bodźce do korzystania na dużą skalę ze zróżnicowanych źródeł finansowania, znajdujących się w rożnych częściach globalnego rynku. Swoboda przepływów kapitałowych charakterystyczna dla procesów glo- 
balistycznych ma więc poważny wpływ na wzrost niestabilności ekonomicznej w świecie i może powodować następujące skutki:

- gwałtowne zwiększenie zmienności i niepewności w wyniku zmian miejsca na rynku przez kapitał, powodowanego zmianami sytuacji ekonomicznej, społecznej i politycznej;

- ograniczenie władzy gospodarczej państw i zdecydowane zmniejszenie zdolności koordynacyjnych na szczeblu państw i szczeblu globalnym;

- osłabienie demokracji i kontroli społecznej nad procesami gospodarczymi;

- zdominowanie gospodarki przez interesy jednostkowe i interesy partykularne niepoddawane procedurom kompromisowym;

- zwiększenie zakresu odrywania procesów inwestowania od tworzenia kapitału (gromadzenia oszczędności);

- zwiększenie łatwości przenoszenia niestabilności na całym rynku globalnym;

- ułatwienie odrywania kursu walut, stóp procentowych i cen papierów wartościowych od tzw. podstaw fundamentalnych;

- zwiększenie tolerowania zadłużenia państw, firm, ludzi ze względu na czasowe odraczanie konsekwencji ekonomicznych;

- wymuszanie na państwach takich działań stabilizacyjnych, które prowadzą w konsekwencji do możliwości korzystania przez podmioty sektora finansowego z sytuacji, w której zyski są prywatyzowane, a straty uspołeczniane;

- odrywanie na coraz większą skalę sfery finansowej gospodarki od sfery realnej. Jak dalej dowodzi ten autor, osłabienie państwa w gospodarce stało się równoznaczne z osłabianiem demokracji. Kreowano optymizm i zaufanie do mechanizmów rynkowych i instytucji finansowych oraz przeświadczenie, że elitom finansowym można w pełni ufać. Państwo tracić zaczęło suwerenność we wszystkich tych sferach, w których wchodziło w konflikt z kapitałem. W takich warunkach nie działała odpowiednio kontrola i nadzór finansowy państwa nad rynkiem kapitałowym. Pojawił się wielki kryzys społeczny, napędzany przeświadczeniem, że automatycznie samoregulujący się świat nie jest w stanie prawidłowo funkcjonować (Szymański, 2009: 41-49).

Także w opinii kolejnego autorytetu, Jana Winieckiego, lista czynników, które odpowiadają za obecny kryzys jest znacznie dłuższa. Według tego ekonomisty za najważniejsze przyczyny obecnego kryzysu można uznać:

- gwałtowne zmiany rozkładu sił gospodarczych na świecie i towarzyszącą im nierównowage;

- procesy globalizacyjne, które przyspieszyły zmiany w rozmieszczeniu produkcji między krajami i kontynentami oraz doprowadziły do realokacji inwestycji finansowych w skali całego świata;

- zmiany demograficzne, w szczególności szybki proces starzenia się społeczeństw państw rozwiniętych;

- burzliwy rozwój rynku instrumentów pochodnych i w efekcie rynków finansowych w ostatnim ćwierćwieczu;

- niezdolność do poprawnej wyceny ryzyka, zwłaszcza (choć niewyłącznie) ryzyka instrumentów pochodnych;

- irracjonalnie optymistyczna ocena szans rozwoju rynku; 
- lekkomyślność instytucji finansowych, które uznawały przewartościowane aktywa, zwłaszcza nieruchomości, za bardzo dobre zabezpieczenie kolejnych udzielanych kredytów;

- niewłaściwe zarządzanie instytucjami finansowymi;

- katastrofalne błędy w polityce gospodarczej, szczególnie w Stanach Zjednoczonych.

W przypadku ostatniego wymienionego elementu, według J. Winieckiego po pierwsze, zawiodła regulacyjna rola rządu, zwłaszcza w odniesieniu do bankowości inwestycyjnej i do rynku instrumentów pochodnych. Po drugie, całkowite fiasko poniosła prowadzona przez System Rezerwy Federalnej polityka pieniężna, czego najbardziej jaskrawym przekładem była błędna decyzja o obniżeniu w latach 2002-2005 stóp procentowych do poziomu najniższego od dziesięcioleci. Po trzecie wreszcie, zawiodła polityka fiskalna, która zamiast ograniczać skalę deficytu oszczędności w Stanach Zjednoczonych doprowadziła w latach 2002-2007 do eksplozji deficytu budżetowego, spowodowanej po części nieodpowiedzialną decyzją o obniżeniu podatków. Ponadto, w opinii tego autora, zauważyć należy, że w rezultacie rozwoju procesu globalizacji udział ChRL i Indii w globalnej produkcji (w PKB mierzonym według parytetu siły nabywczej - PPP) wzrósł z 8\% do 23\%. Towarzyszył temu gwałtowny wzrost znaczenia obu wielkich gospodarek na światowym rynku (na przykład udział ChRL w światowym eksporcie wzrósł z poniżej $1 \%$ na początku lat 80 . XX wieku do ponad $8 \%$ obecnie). Szybkiemu rozwojowi ChRL i relatywnie malejącemu znaczeniu Stanów Zjednoczonych towarzyszyła i nadal towarzyszy gigantyczna nierównowaga. USA w coraz większym stopniu finansowały swój wysoki poziom życia, pożyczając kapitał za granica, a ChRL utrzymywała na niezwykle wysokim poziomie stopy oszczędności, dzięki którym (wraz z innymi krajami Dalekiego Wschodu) udzielały USA ogromnego kredytu, pozwalając na chroniczną, nadmierną konsumpcję. Innymi słowy, „amerykańska cywilizacja życia na kredyt spotkała się z azjatycką kulturą oszczędności”, co doprowadziło do powstania ogromnego zadłużenia Stanów Zjednoczonych wobec reszty świata. W ostatnim dwudziestopięcioleciu dla inwestorów atrakcyjne stały się państwa (rynki wschodzące) wcześniej wyłączone z globalnego rynku, Instytucje finansowe zdywersyfikowały swoje portfele, obejmując nimi aktywa z całego świata. Zjawiska te wspomagał postęp technologiczny, zwłaszcza w dziedzinie telekomunikacji, a także obserwowane od ćwierćwiecza trendy liberalizacyjne w gospodarce światowej. Jednocześnie oznaczało to drastyczne zmniejszenie możliwości nadzoru nad działalnością instytucji finansowych, utrudnioną ocenę ryzyka związanego z inwestycjami, łatwiejszy proces formowania się i utrzymywania długookresowej nierównowagi oraz wzrost ryzyka rozprzestrzeniania się kryzysów finansowych poprzez przejmowanie problemów od innych gospodarek (Kryzys, 2009: 47-59).

Znacznie bardziej radykalną opinią na temat szerszych niż techniczne przyczyn współczesnego kryzysu dzieli się z czytelnikami laureat nagrody Nobla w dziedzinie ekonomii, Joseph E. Stiglitz pisząc: „Współczesna ekonomia, z jej wiarą w wolne rynki i globalizację, obiecywała prosperity dla wszystkich. Głośno wychwalana Nowa Gospodarka (New Economy) - oszałamiające innowacje charakterystyczne dla drugiej połowy XX wieku, włącznie z deregulacją i inżynierią finansową - miały zagwarantować lepsze zarządzanie ryzykiem i położyć kres cyklom koniunkturalnym. A jeżeli nawet połączenie Nowej Gospodarki i nowoczesnej wiedzy ekonomicznej nie zdołałoby 
wyeliminować fluktuacji gospodarczych, to miało je przynajmniej ujarzmić. Wielka Recesja - zdecydowanie najgorsze osłabienie koniunktury gospodarczej od czasu Wielkiego Kryzysu, który miał miejsce 75 lat temu zdruzgotała te iluzje i zmusza nas do przemyślenia pewnych długo hołubionych poglądów. Przez ćwierć stulecia prym wiodły doktryny wolnorynkowe: wolne i niczym nieskrępowane rynki są efektywne; jeżeli dojdzie do błędu, rynki same szybko go skorygują. Najlepszym rządem jest mały rząd; a regulacja tylko przeszkadza w innowacyjności. Banki centralne powinny być niezależne i skupiać się wyłącznie na utrzymaniu niskiej inflacji. [...] Ja sam jestem przekonany, że rdzeniem każdej odnoszącej sukcesy gospodarki są rynki. Jednak pozostawione samym sobie rynki nie działają dobrze. W tym sensie przynależę do tradycji znakomitego brytyjskiego ekonomisty Johna Maynarda Keynesa, którego myśl góruje nad studiami z zakresu nowoczesnej ekonomii. Rząd musi odgrywać swoją rolę nie tylko ratując gospodarkę, gdy zawiodły rynki, ale również regulując te rynki po to, żeby zapobiec ich niesprawnościom - takim, jakich doświadczamy obecnie. Gospodarkom potrzebna jest równowaga między rolą rynków i rolą rządów - przy wydatnym wkładzie ze strony instytucji nierynkowych i pozarządowych. W ciagu minionych 25 lat ta równowaga została w Ameryce zachwiana, a potem ten zachwiany układ został narzucony innym państwom świata. [...] Gdy w 2008 roku gospodarka światowa weszła w fazę «jazdy bez trzymanki» (ang. freefall) podobny los spotkał nasze przekonania. Długo obowiązujące poglądy Ameryki i jej bohaterów na temat ekonomii także uległy niekontrolowanej zapaści. Wielka Recesja 2008 roku jest nieuchronną konsekwencją polityki wdrażanej w poprzedzających ją latach. Że ta polityka została ukształtowana przez uprzywilejowane interesy - interesy rynków finansowych - jest jasne. Bardziej skomplikowaną rolę odegrała ekonomia. Na długiej liście tych, których należy obwiniać za ten kryzys, umieściłbym ekonomistów, dlatego że to środowisko zawodowe dostarczało tym uprzywilejowanym grupom interesu argumentów opiewających efektywne i samoregulujące się rynki - mimo że postępy w ekonomii w czasie dwóch ostatnich dekad ujawniły ściśle ograniczone warunki, w których ta teoria się sprawdza. Obecny kryzys odsłonił fundamentalne wady systemu kapitalistycznego, a przynajmniej tej szczególnej wersji kapitalizmu, która uformowała się w drugiej połowie XX wieku w Stanach Zjednoczonych (czasem nazywa się ją kapitalizmem w stylu amerykańskim). Oprócz finansów, pod każdym względem, wiele kluczowych sektorów gospodarki Stanów Zjednoczonych przeżywa kłopoty, włącznie z ochroną zdrowia, energetyką i produkcją przemysłową. Jednak problemy, którymi trzeba się zająć, nie ograniczają się wyłącznie do Stanów Zjednoczonych. Brak równowagi $\mathrm{w}$ handlu globalnym cechujący świat przed kryzysem nie zniknie sam z siebie. W zglobalizowanej gospodarce nie można w pełni rozwiązać problemów Ameryki nie ujmując tych problemów szerzej. O globalnym wzroście zdecyduje globalny popyt; Stanom Zjednoczonym trudno będzie doprowadzić do trwałego ożywienia - i uniknąc choroby w stylu japońskim - o ile gospodarka światowa nie będzie mocna. Tymczasem, doprowadzenie do wzmocnienia gospodarki światowej może być trudne, dopóki jedna część świata nadal wytwarza znacznie więcej niż konsumuje, a druga - ta, która powinna oszczędzać, żeby sprostać potrzebom związanym ze starzeniem się ludności - nadal konsumuje znacznie więcej niż wytwarza" (Stiglitz, 2010: $\mathrm{xv}-\mathrm{xxx})$. 
Współczesny kryzys bez wątpienia dowiódł ewidentnej konieczności poprawy funkcjonowania sfery finansowej poprzez wzrost koordynacyjnej, kontrolnej i nadzorczej roli państwa w gospodarce. Zderegulowane i źle zarządzane instytucje finansowe oderwały się od realnej gospodarki, dążąc w pierwszej kolejności do maksymalizacji zysków, a nie zdobycia szerokiego zaufania publicznego. Państwo i jego instytucje muszą też zadbać o to, aby działalność rynków finansowych była znacznie bardziej transparentna i zrozumiała dla przeciętnego obywatela. W niektórych przypadkach wręcz powinno go chronić się przed możliwością pozyskania ryzykownych kredytów i nadmiarem nieprzejrzystych instrumentów pochodnych na rynku (derywatów), z których potencjalnie może on korzystać. Na błędy w funkcjonowaniu rynków finansowych nałożyła się przy tym krótkowzroczna i szkodliwa polityka gospodarcza administracji amerykańskiej i Fed, której negatywne skutki, w wyniku wielkiej współzależności rozwojowej cechującej procesy globalizacji, odczuła cała gospodarka światowa.

Przy analizie problemu przyczyn i skutków kryzysu istnieje przy tym groźba skupienia się jedynie na technicznym aspekcie problemu, związanym z poprawą nadzoru nad rynkiem finansowym i wzrostem jego przejrzystości. Tymczasem, aby gospodarka światowa w przeciagu kilku najbliższych lat wróciła do stanu równowagi, wzrósł dobrobyt społeczny i optymizm społeczny potrzebne są znacznie poważniejsze zmiany. Zredefiniowaniu powinny ulec procesy globalizacyjne, tak aby zarówno w gospodarkach państw rozwiniętych, jak i rozwijających się było mniej dysproporcji dochodowych, za to więcej pracy za godziwe stawki. Sam rozwój sektora usług IT, bez niezbędnej reindustrializacji, oczekiwań tych w rozwiniętych państwach Triady i dynamicznych rynkach wschodzących z BRICS na czele nie spełni. Państwa biedne, z 50 LDC's na czele z kolei nie chcą dłużej odgrywać roli wyłącznie zaplecza taniej siły roboczej dla tzw. sweatshops (katorżniczych warsztatów) korporacji transnarodowych wywodzących się z państw Triady, dodatkowo transferujących zyski i pozbawiających je wypracowanej wartości dodanej. Przydatne byłoby więc stworzenie podstaw nowego globalnego ładu gospodarczego, zawierających porozumienie na linii Stany Zjednoczone-Azja Południowo-Wschodnia (szczególnie ChRL)-Unia Europejska. Niezbędne jest uporządkowanie finansów publicznych w wielu państwach świata i stopniowe obniżenie wielkości ich zadłużenia. Najlepszym przykładem jest tu pogrążona w poważnym kryzysie gospodarczym unijna grupa PIIGS. Trwałemu zmniejszeniu musi ulec też skala globalnej nierównowagi powodowanej stałym niedoborem oszczędności i kapitału w jednych gospodarkach, czemu towarzyszy nadmierna konsumpcja (USA), a nadmiarem w innych, w których popyt wewnętrzny jest nadal zbyt słaby (ChRL). Bez działań tych trudno w perspektywie średnio- i długoterminowej wyobrazić sobie wyraźną poprawę sytuacji ekonomicznej i społecznej w świecie.

\section{Bibliografia}

Carter G. (2011/2012), Na krawędzi. Opowieści o kryzysie. Prawdziwe historie z Wall Street z magazynu Vanity Fair", przełożyli J. Lang, A. Małecka, M. Mańko-Kuzaj, Warszawa.

Globalizacja, kryzys i co dalej? (2010), pod red. G. W. Kołodko, Warszawa. 
Gospodarka w warunkach kryzysu (2010), pod red. S. Antkiewicz, M. Pronobis, Warszawa.

Gruszecki T. (2012), Świat na dlugu, Lublin.

Harman Ch. (2011), Kapitalizm zombi. Globalny kryzys i aktualność myśli Marksa, przełożyła H. Jankowska, Warszawa.

Jurek M., Marszałek P. (2010), Kryzys subprime i kryzys azjatycki-analiza porównawcza, w: Gospodarka w warunkach kryzysu, pod red. S. Antkiewicz, M. Pronobis, Warszawa.

Krugman P. (2012), Powrót recesji. Kryzys roku 2008, przełożył M. Ruszczyński, Warszawa.

Kryzys globalny. Poczatek czy koniec? (2009), pod red. J. Winiecki, Gdańsk.

Nawrot W. (2009), Globalny kryzys finansowy XXI wieku. Przyczyny, przebieg, skutki, prognozy, wydanie I, Warszawa.

Platon na Wall Street, Konserwatywne refleksje o kryzysie ekonomicznym (2010), pod red. J. Kloczkowski, J. Price, Kraków.

Rajan R. G. (2012), Linia uskoku. Ukryte rysy, które wcią̇ zagrażaja światowej gospodarce, przełożyli T. Krzyżanowski, M. Lang, Warszawa.

Roubini N., Mihm S. (2011), Ekonomia kryzysu - Wstęp do wydania polskiego: G. W. Kołodko, Warszawa.

Roubini N., Żaden kraj nie jest wyspa, wywiad z portalu POLITYKA.PL, http://www.polityka.pl/rynek/edukatorekonomiczny/1517794,1,wywiad-nouriel-roubini-amerykanski-ekonomista-ktory-przewidzial-kryzys.read (5.09.2103).

Smoczyński W. (2012), Bez nauczki, „Polityka, Niezbędnik inteligenta”, nr 1.

Smoczyński W. (2012), Byt sobie bank, „Polityka, Niezbędnik inteligenta”, nr 1.

Smoczyński W. (2012), Świat na bańce, „Polityka, Niezbędnik inteligenta”, nr 1.

Stiglitz J. E. (2010), Freefall jazda bez trzymanki. Ameryka wolne rynki i tonięcie gospodarki światowej, Warszawa.

Szymański W. (2009), Kryzys globalny. Pierwsze przybliżenie, Warszawa.

Taylor J. B. (2010), Zrozumieć kryzys finansowy Przyczyny, skutki, interpretacje, przekład Ł. Goczek, Warszawa.

Współczesny kryzys gospodarczy. Przyczyny - przebieg - skutki (2009), (red.) J. L. Bednarczyk, S. I. Bukowski, J. Misala, wydanie I, Warszawa.

\title{
STRESZCZENIE
}

Autor w prezentowanym artykule skupia się na analizie przyczyn i skutków bieżącego kryzysu finansowego w świecie, znanego jako „kryzys 2008+”. Szczególny nacisk położony został na porównanie argumentów krytyków i zwolenników neoliberalnego kierunku rozwoju współczesnych rynków finansowych. Przybliżeniu podlega zarówno praktyczny, jak i teoretyczny wymiar problemu, z ogólnie nakreślonymi propozycjami wyjścia z kryzysu włącznie.

\section{CAUSES OF GLOBAL FINANCIAL CRISIS $2008+$. ANALYSIS AND COMPARISON OF SELECTED OPINIONS}

\begin{abstract}
The author in the presented article focuses on the causes and consequences of the current financial crisis in the world, known as the ,crisis $2008+$ +. Particular emphasis was placed on com-
\end{abstract}


paring the arguments of critics and supporters of the neo-liberal development direction of modern financial markets. Approximately is both practical and theoretical dimension of the problem, with generally outlined proposals for ending the crisis included. 